\title{
Progressive Development and Challenges Faced by Solar Rotary Desiccant-Based Air-Conditioning Systems: A Review
}

\author{
Ranjan Pratap Singh *(D) and Ranadip K. Das \\ Department of Mechanical Engineering, Indian Institute of Technology (ISM), Dhanbad 826 004, India; \\ randip@iitism.ac.in \\ * Correspondence: ranjansingh@mece.ism.ac.in
}

Citation: Singh, R.P.; Das, R.K. Progressive Development and Challenges Faced by Solar Rotary Desiccant-Based Air-Conditioning Systems: A Review. Processes 2021, 9, 1785. https://doi.org/10.3390/ pr9101785

Academic Editors: Mwesigye Aggrey and Mohammad Moghimi Ardekani

Received: 22 July 2021

Accepted: 27 September 2021

Published: 8 October 2021

Publisher's Note: MDPI stays neutral with regard to jurisdictional claims in published maps and institutional affiliations.

Copyright: (c) 2021 by the authors. Licensee MDPI, Basel, Switzerland. This article is an open access article distributed under the terms and conditions of the Creative Commons Attribution (CC BY) license (https:// creativecommons.org/licenses/by/ $4.0 /)$.

\begin{abstract}
A rotary desiccant-based air-conditioning system is a heat-driven hybrid system which combines different technologies such as desiccant dehumidification, evaporative cooling, refrigeration, and regeneration. This system has an opportunity to utilize low-grade thermal energy obtained from the sun or other sources. In this paper, the basic principles and recent research developments related to rotary desiccant-based cooling systems are recalled and their applications and importance are summarized. It is shown that with novel system configurations and new desiccant materials, there is great potential for improving the performance and consistency of rotary desiccant systems; at the same time, the use of solar energy for regeneration purposes can minimize the operating cost to a great extent. Some examples are presented to demonstrate how rotary desiccant air conditioning can be a promising solution for replacing traditional vapor-compression air-conditioning systems. Recent advances and ongoing research related to solar-powered hybrid rotary desiccant cooling systems are also summarized. The hybrid systems make use of a vapor-compression system in order to have better operational flexibility. These systems, although they consume electrical energy, use solar energy as the principal source of energy, and hence, significant savings of premium energy can be obtained compared to conventional vapor-compression systems. However, further research and development are required in order to realize the sustainable operation of solar rotary desiccant air-conditioning systems, as solar energy is not steady. Reductions in capital cost and size, along with improvements in efficiency and reliability of the system is still needed for it to become a player in the market of air conditioning.
\end{abstract}

Keywords: desiccant wheel; solar energy; air conditioning; hybrid system; vapour compression refrigeration

\section{Contents}

1. Introduction

2. The Desiccant Materials

2.1. Silica Gel

2.2. Activated Alumina

2.3. Molecular Sieve

2.4. Advanced Desiccant Materials

\subsubsection{Polymer Desiccants}

2.4.2. Composite Desiccant

3. Working Principles of Rotary Desiccant Cooling Systems

3.1. The Rotary Desiccant Dehumidification System

3.2. The Cooling System

3.3. The Regenerative Heating Source

4. Research Progress in Configuration of Rotary Desiccant Cooling System

4.1. Pennington Cycle 


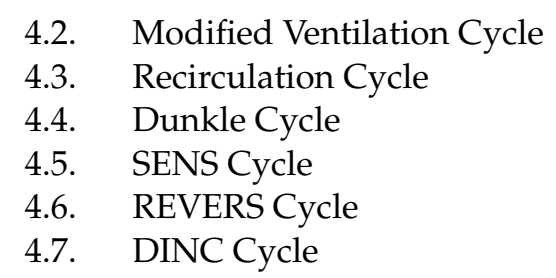

5. Use of Solar Energy for Rotary Desiccant Cooling System

5.1. Solar Collectors

5.2. Nontracking Solar Collectors

5.2.1. Flat-Plate Solar Collectors (FPSCs)

5.2.2. Evacuated Tube Solar Collectors (ETSCs)

5.2.3. Compound Parabolic Solar Collectors (CPSC)

6. Recent Advancements in the Field of Desiccant Cooling Systems

7. Recent Applications of Solar-Assisted Desiccant Dehumidification and Cooling System

7.1. Solar Driven Rotary Hybrid Desiccant Air-Conditioning Systems

7.2. Use of Rotary Hybrid Desiccant Cooling for Preservation Purpose

8. Conclusions

Reference

\section{Introduction}

According to the International Energy Agency in 2012, HVAC systems in the building sector are the most energy consuming devices, contributing $10-20 \%$ of the final energy consumption in developed countries. Thus, the increase in energy efficiency for HVAC systems plays an important role in energy policies worldwide [1]. Providing cooling by utilizing renewable energy, such as solar energy, is one solution to address the energy issues. Desiccant-based solar cooling is one of the most promising methods of utilizing solar energy for the purpose of air conditioning. This system is a combination of dehumidification, refrigeration, cooling with the help of an evaporative cooler, and finally regeneration of the desiccant system by a heat source, in order to provide and maintain the desired room temperature and relative humidity with enhanced efficiency of energy use [2]. So, compared to conventional systems, desiccant-based air conditioning provides efficient control of room temperature along with relative humidity, while consume less electrical energy [3]. Almost all air-conditioning systems essentially handle two kinds of load, namely sensible load and latent load. The sensible load is due to temperature differences, while latent load is due to moisture [4]. Conventional air-conditioning systems do not have any separate arrangements for handling sensible and latent load. Here, the evaporator coil can handle both sensible as well as latent load. When handling latent load in conventional air-conditioning systems, it is necessary to maintain the temperature of the evaporator coil below the dew point temperature of the inlet air. So it is again required to reheat, which implies poorer energy efficiency. In desiccant-based air-conditioning systems, latent cooling is performed by desiccant dehumidification and sensible cooling by evaporative cooling or refrigeration. Thus, a considerable part of expensive vapor-compression refrigeration is replaced by inexpensive evaporative cooling.

The desiccant dehumidification and cooling system (DDCS) is the best alternative for the VC system as it overcomes the traditional system's disadvantages and is more economical and easily accessible. The DDCS decreases the operational costs and work more significantly when powered by solar energy [5-7].

The conventional reheat system not only consumes excess electrical energy because of low energetic efficiencies, but it is also responsible for damaging our environment. These two reasons are responsible for the need to investigate the development of an alternative HVAC system which does not have any adverse effect on our environment, as well as being able to use low-grade sources of energy. Desiccant-based air-conditioning systems utilizing solar energy fulfil both the demands of researcher, so it is one of the most promising 
choices [8]. Several experimental setups have been built and tested across the world to study the feasibility and effectiveness of using solar-powered solid desiccant cooling systems instead of traditional VC systems. In hybrid systems, both solar-energy- and electricity-driven refrigeration systems are utilized, and progress has been made in making solar energy a primary energy source [9] This paper intends on discussing the various aspects of recent efforts in the field of desiccant dehumidification and cooling systems, and the use of solar energy in the regeneration process of desiccant wheels to improve the efficiency of its application. The study focusses on different advanced desiccant materials which may be considered as possible candidates for desiccant cooling systems, and on the progress and applications of solar technology in recent decades for the purpose of airconditioning. At the same time, the obstacles and research and development requirements for future work are also summarized.

\section{The Desiccant Materials}

Desiccants are absorbents which have very high attraction towards water vapor. Desiccants are present either in solid form or in liquid form. Solid desiccants are extremely porous and use chemical adsorption processes in order to adsorb water vapor. Silica gel, activated alumina, synthetic polymers, natural zeolites and molecular sieves are some examples of solid desiccants. For the purpose of dehumidification and cooling Silica gels are used widely [10-14]. Liquid desiccants are commonly very strong solutions of ionic salts. Calcium chloride or lithium chloride, and nearly-organic liquids, such as tri-ethylene glycol are the common examples of liquid desiccants. Some widely used solid desiccants and their properties are discussed in the following sections.

\subsection{Silica Gel}

Because of its very high attraction towards moisture, silica gel is generally used for air-conditioning purposes. It is a naturally available mineral which is nontoxic, as well as odorless. It has a porosity grater then $70 \%$, surface area in the order of $650 \mathrm{~m}^{2} / \mathrm{g}$, with pour sizes of 2-3 nm (type A) to $0.7 \mathrm{~nm}$ (type B) and a heat-absorption capacity of about $2800 \mathrm{~kJ} / \mathrm{kg}$ [15]. Some types of silica gel are macroporous whereas some are microporous. Macroporous silica gel gets saturated easily, whereas microporous silica gel can absorb water vapor for a longer time. Some types of silica gel change their color from blue to pink while absorbing water. A regenerated air stream is used for regeneration of silica gel in which absorbed water is removed. The regenerated air temperature generally varies between 90 to $150{ }^{\circ} \mathrm{C}[16,17]$.

\subsection{Activated Alumina}

Activated alumina is prepared in thermal processes in which structural properties are controlled by using temperature and duration of the thermal process. Essentially, these are oxides and hydrides of aluminum with a surface area of $150-500 \mathrm{~m}^{2} / \mathrm{g}$, pour size of $1.5-6 \mathrm{~nm}$ and heat-adsorption capacity of about $3000 \mathrm{~kJ} / \mathrm{kg}$. They are used frequently for desiccant dehumidification and cooling applications $[18,19]$.

\subsection{Molecular Sieves}

Molecular sieves, also called synthetic zeolites, are crystalline aluminosilicates prepared in thermal processes. The composition of the ingredient materials and the temperature control the structure and surface features. Synthetic zeolite can hold moisture strongly, and hence is used for different dehumidification and air-conditioning applications [20-23].

\subsection{Advanced Desiccant Material}

These are the newly developed desiccant materials, such as composite desiccant and polymeric desiccant, with better properties that can be used in place of common desiccant materials. 


\subsubsection{Polymer Desiccants}

Essentially, a polymer is a substance made up of macromolecules. In comparison with silica gel, polymer desiccants enable 2-3 times greater sorption capacity [24]. Polymer desiccant gives a better result when used in a condition of higher relative humidity and low regeneration temperature [25]. Synthetic polymers can be used as advanced desiccant materials because they are capable of adsorbing up to $80 \%$ of their own weight in water and have the potential of being adjusted to realize desired water adsorption isotherms.

\subsubsection{Composite Desiccant}

Composite Desiccant is made by infusing hygroscopic salt into the porous desiccant material. The development of composite desiccants such as silica-gel- and haloids-based composite materials not only increases the dehumidification capacity of silica gel, but also minimizes the problem of corrosion with haloids. At the same time, regeneration temperature is considerably decreased, thus enabling the usage of lower-grade heat sources. A composite desiccant wheel can remove approximately $50 \%$ or more moisture from air than a conventional wheel [26].

\section{Working Principles of Rotary Desiccant-Based Cooling Systems}

In rotary desiccant-based air-conditioning systems, latent cooling is performed by desiccant dehumidification and sensible cooling is performed by a low-cost evaporative cooler. So, it is a combination of the dehumidification of the process air by passing it through the rotary desiccant wheel followed by cooling of the dehumidified air to the required indoor conditions. This system is made continuous by a regeneration process in which heated regeneration air is made to flow through the desiccant wheel so that the water vapor which is accumulated from the process air is removed and the wheel is made available to absorb water vapor from the process air in the next cycle. Therefore, the desiccant cooling system mainly contains three components: the desiccant dehumidification system, the cooling system, and the regenerative heating source.

\subsection{The Rotary Desiccant Dehumidification System}

The principle of rotary desiccant dehumidification is shown in Figure 1. A process in which a fresh-air stream is dehumidified while flowing through a rotary desiccant wheel is known as desiccant dehumidification, and since air is also heated during the process, it is shown as a dehumidification and heating process on the psychometric chart. There is another type of air stream, known as regeneration air, which is first heated and then made to flow through the wheel to drive off the absorbed moisture from the desiccant. Consequently, the regeneration air is humidified and cooled. This process is known as regeneration of the desiccant wheel.

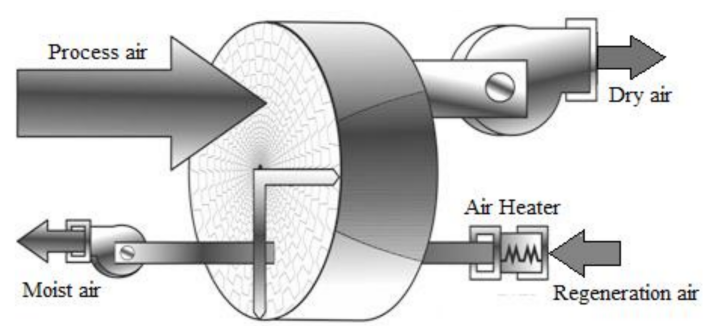

Figure 1. Rotary Desiccant Dehumidification System.

\subsection{The Cooling System}

The cooling system is mainly used to handle sensible load. Generally, an evaporative cooling system or cooling coil of a traditional vapor-compression system are used for this purpose. With the implementation of a desiccant wheel, a number of heat exchanges are also used to preliminarily cool the dry and warm air stream after the desiccant wheel with 
the help of cabin and ambient air, before it is further cooled by an evaporative or traditional cooling unit.

\subsection{The Regenerative Heating Source}

An energy source is required in order to increase the temperature of regeneration air which can supply the necessary thermal energy for removing the moisture absorbed during the sorption phase from the desiccant wheel. A variety of possible energy sources such as an electrical heater, gas heating system, waste heat from different sources, and solar energy are generally used as a regeneration energy source for desiccant wheel.

\section{Research Progress in Configuration of Rotary Desiccant Cooling System}

Various cycles have been developed for the improvement of thermal performance, i.e., $\mathrm{COP}$ and cooling capacity of rotary desiccant-based air-conditioning system. This section describes the research progress and advancement of these cycles.

\subsection{Pennington Cycle}

The rotary desiccant cooling cycle, as shown in Figure 2, was proposed by Pennington in the mid 1950's and is named the Pennington cycle or ventilation cycle. In this cycle, ambient air and exhaust air streams pass through different stages of heat and desiccant wheels. In the first stage, ambient air passes through desiccant wheel, where air moisture is absorbed and temperature is increased. This hot, dry air then passes through a heat exchanger (HEx), where sensible cooling takes place. The process air is then passed through the evaporative cooler (EC), where its temperature is further lowered. Finally, the air is supplied to the room at EC exit conditions.
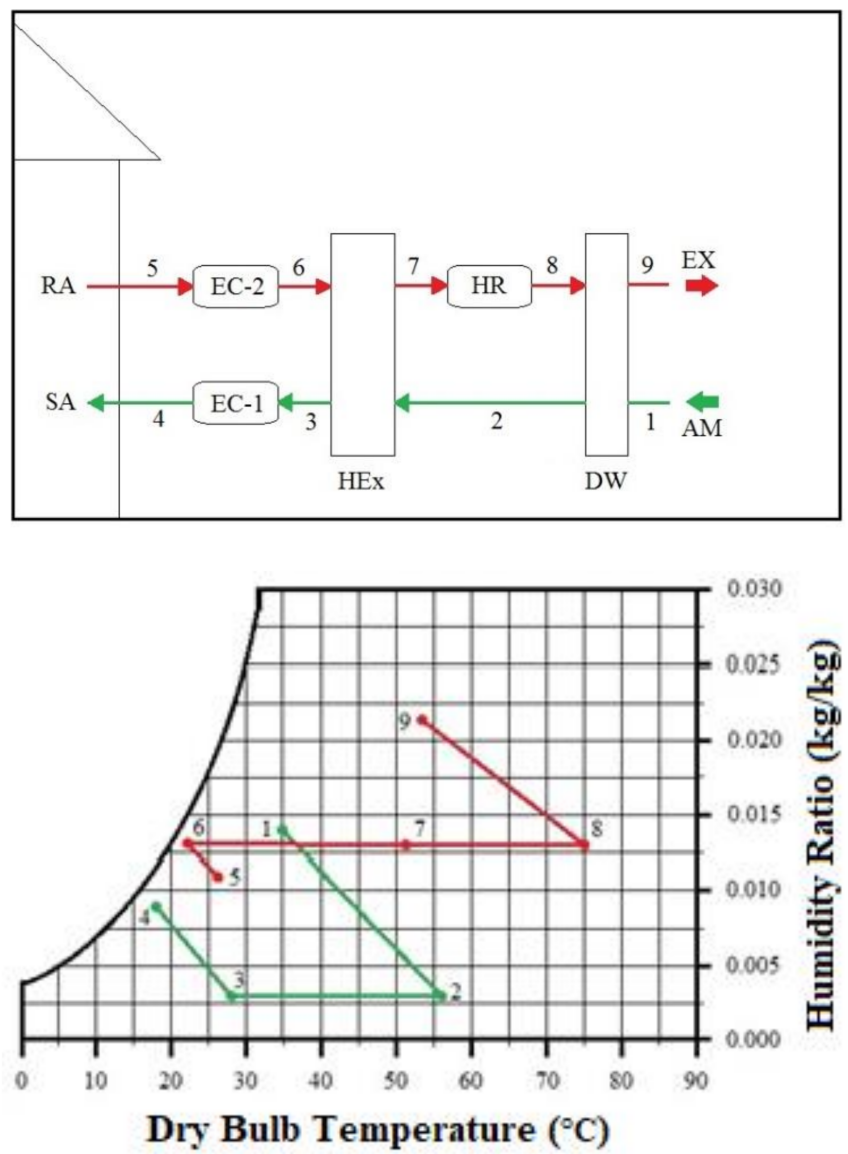

Figure 2. Pennington Cycle. 
To increase the precooling of the supply air, which is encouraged by using a heat exchanger, return air collected at stage five is passed through another EC where it is cooled before entering the HEx. The dehumidified air first preheats the return air, which is then passed through the heat source in order to increase its temperature for regeneration of the desiccant wheel. This return air, after passing through the desiccant wheel, is exhausted at stage nine [27]. Based on an experiment conducted with a lithium chloride desiccant wheel operating under ARI conditions (i.e., $36{ }^{\circ} \mathrm{C}$ DBT, $45 \%$ RH, room condition: $26{ }^{\circ} \mathrm{C}$ DBT, $55 \%$ $\mathrm{RH})$, a COP of 0.78 and a regeneration temperature of $72.3^{\circ} \mathrm{C}$ was reported [28], whereas COP of 0.345 was reported with a low-performance natural zeolite desiccant wheel [29]. By using a silica-gel desiccant wheel and an aluminum heat wheel with an effectiveness of $0.7, \mathrm{COP}$ value was reported in the range of $0.28-0.59$, when operated under ambient conditions [30].

\subsection{Modified Ventilation Cycle}

A modified ventilation cycle, as shown in Figure 3, is proposed, where ambient air is used as process air as well as regeneration air. Since the humidity ratio and temperature of ambient air are higher than the return air, the COP and the specific cooling capacity would be reduced compared with during the standard Pennington cycle.
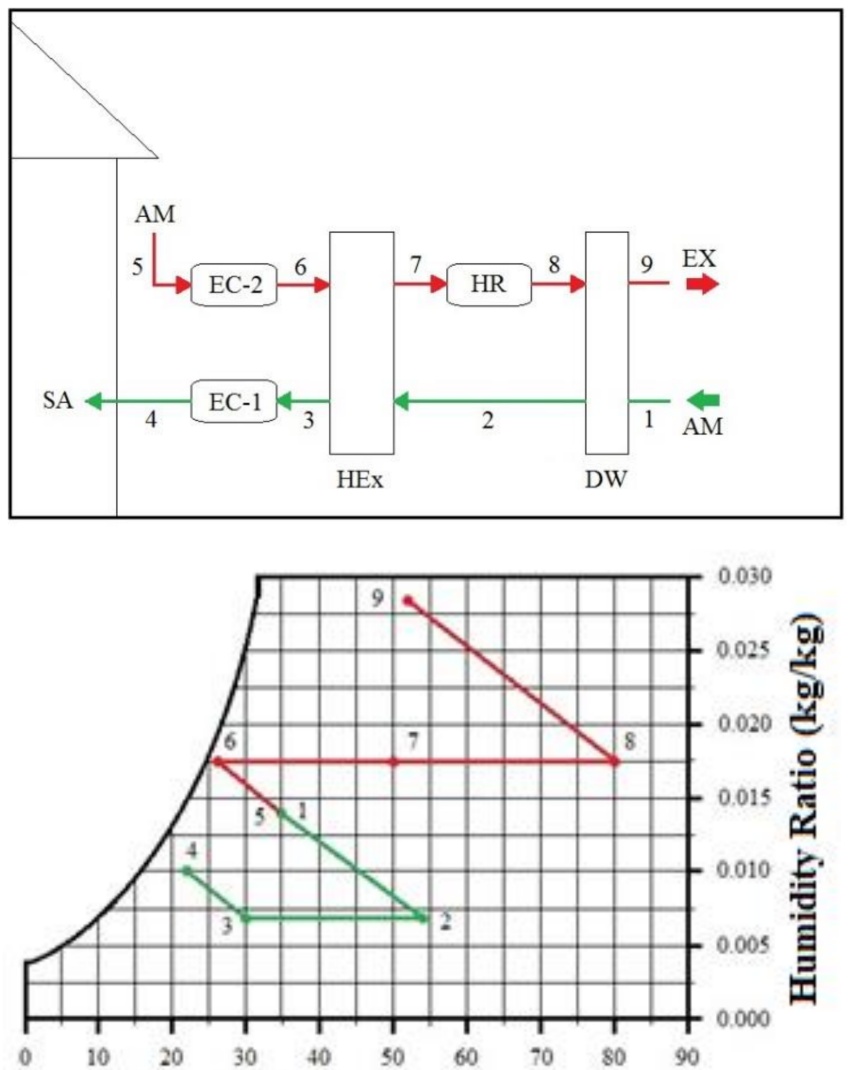

Dry Bulb Temperature $\left({ }^{\circ} \mathrm{C}\right)$

Figure 3. Modified Ventilation Cycle.

\subsection{Recirculation Cycle}

The recirculation cycle, as shown in Figure 4, was developed to elevate the cooling capacity. This cycle reuses the return air as process air. The recirculation of the process air might be disadvantageous, because a solid desiccant wheel requires a high regeneration temperature. A lack of fresh air is also a drawback of this cycle. The value of thermal COP of this cycle was reported to be closer to the COP of ventilation cycle, i.e., 0.8 [31]. 

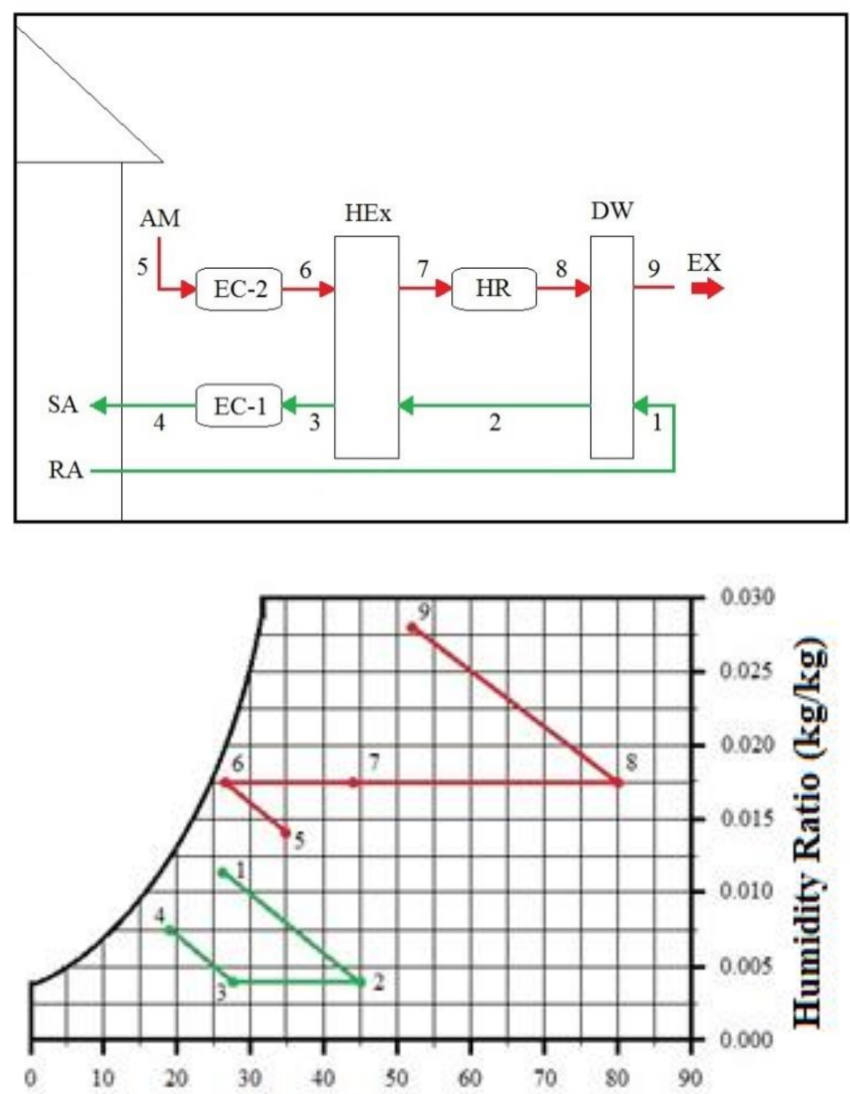

Dry Bulb Temperature $\left({ }^{\circ} \mathrm{C}\right)$

Figure 4. Recirculation Cycle.

\subsection{Dunkle Cycle}

In the Dunkle cycle, as shown in Figure 5 [32], return air is used as process air. The return air first passes through EC-1, where evaporative cooling takes place. Then, this air passes through HEx-1 to cool the process air before it enters the EC-2. This results in a rise in return air temperature, which then passes through the desiccant wheel, where its moisture gets absorbed and it is further heated. This hot and dry process air then passes through HEx-2, where it rejects some amount of heat to the ambient air used for regenerating the DW. The process air is then further cooled by the return air in HEx-1 and evaporatively cooled in EC-2, before being supplied to the conditioned space. In the EC-2, the air gets cooled, and its moisture content is increased. A limitation of this cycle is that it lacks fresh air, similarly to the Recirculation cycle.

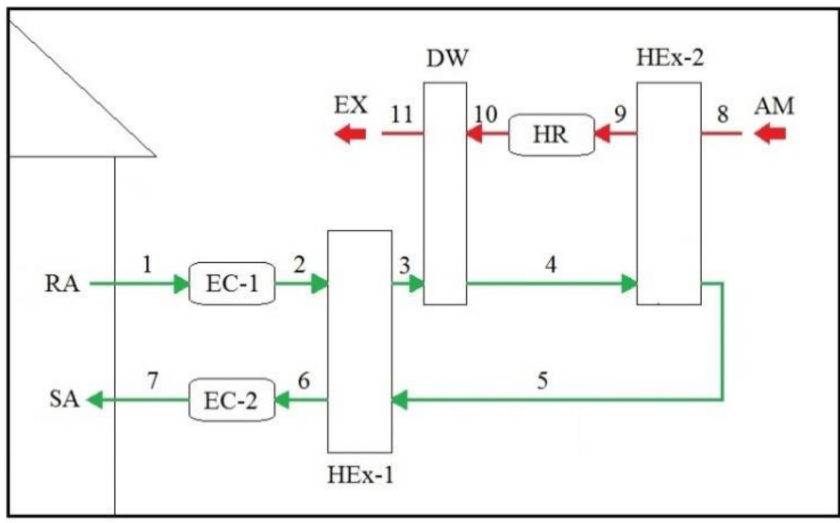

Figure 5. Cont. 


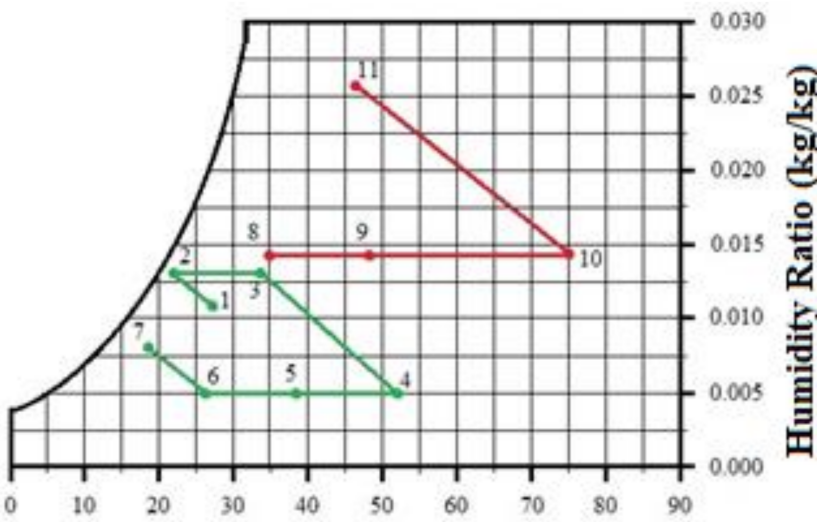

Dry Bulb Temperature $\left({ }^{\circ} \mathrm{C}\right)$

Figure 5. Dunkle Cycle.

\subsection{SENS Cycle}

A simplified advanced desiccant cycle, as shown in Figure 6, named as SENS cycle, was proposed by Maclaine-cross [33]. Ambient air is processed through DW where it is dehumidified, and subsequently it is sensibly cooled while passing through two heat exchangers.
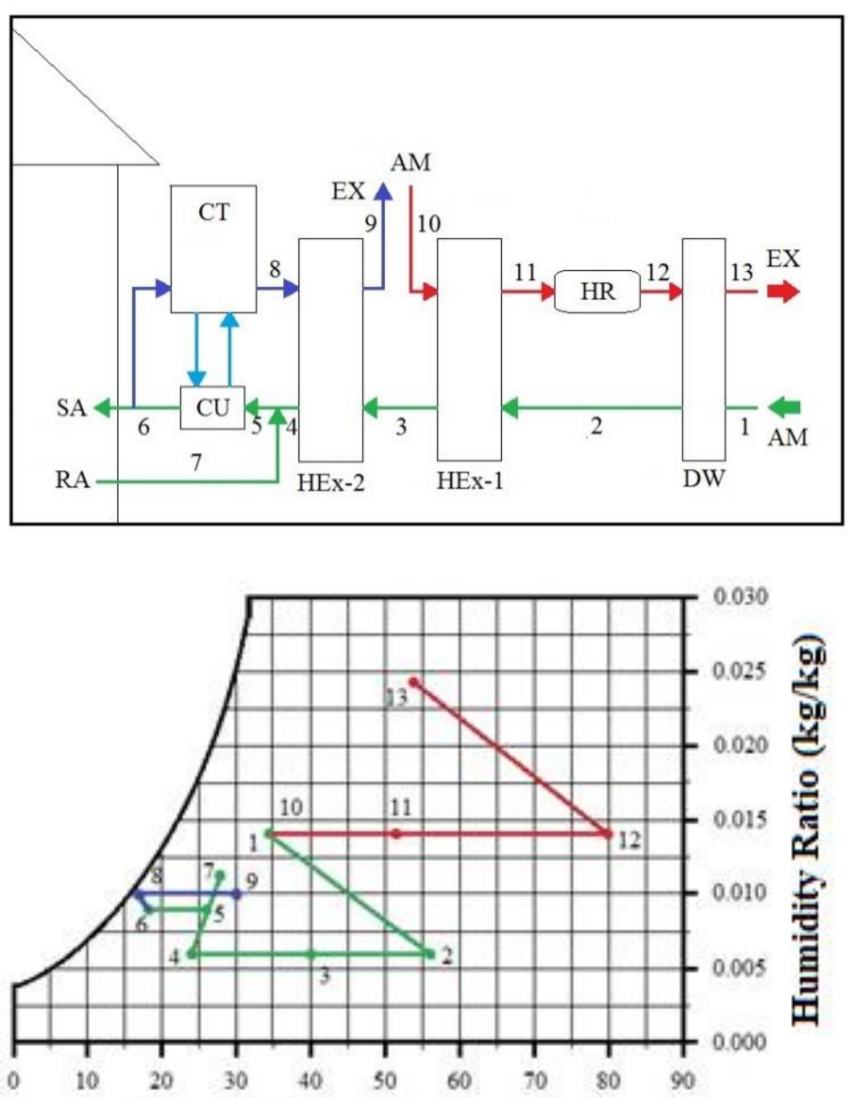

Dry Bulb Temperature $\left({ }^{\circ} \mathrm{C}\right)$

Figure 6. SENS Cycle.

Before passing through the cooling unit (CU), this air is mixed with some amount of return air, and the mixed air gets cooled in $\mathrm{CU}$ by exchanging heat with cold water from the cooling tower (CT). Some amount of this air is redirected to the $\mathrm{CT}$ and is subsequently 
exhausted after passing through the heat exchanger (HEx-2). The remaining air is supplied to the space for air conditioning.

On the regeneration side, ambient air is preheated in Hex-1 by the humidified air and reheated in the heater (HR), before passing through the DW, absorbing moisture from it, and then is exhausted back to the outdoors. The COP of SENS cycle with simulation of ideal components was reported to be 2.58 under ARI conditions, whereas the COP of the ventilation cycle was 1.04 in the same conditions [34]. From experiments, COP ranging from 0.61 to 1.97 was observed at regeneration temperatures varying from 54.1 to $90.4{ }^{\circ} \mathrm{C}$ [35].

\subsection{REVERS Cycle}

REVERS cycle, as shown in Figure 7, is a simplified version of the SENS cycle with the only change being the removal of one HE.
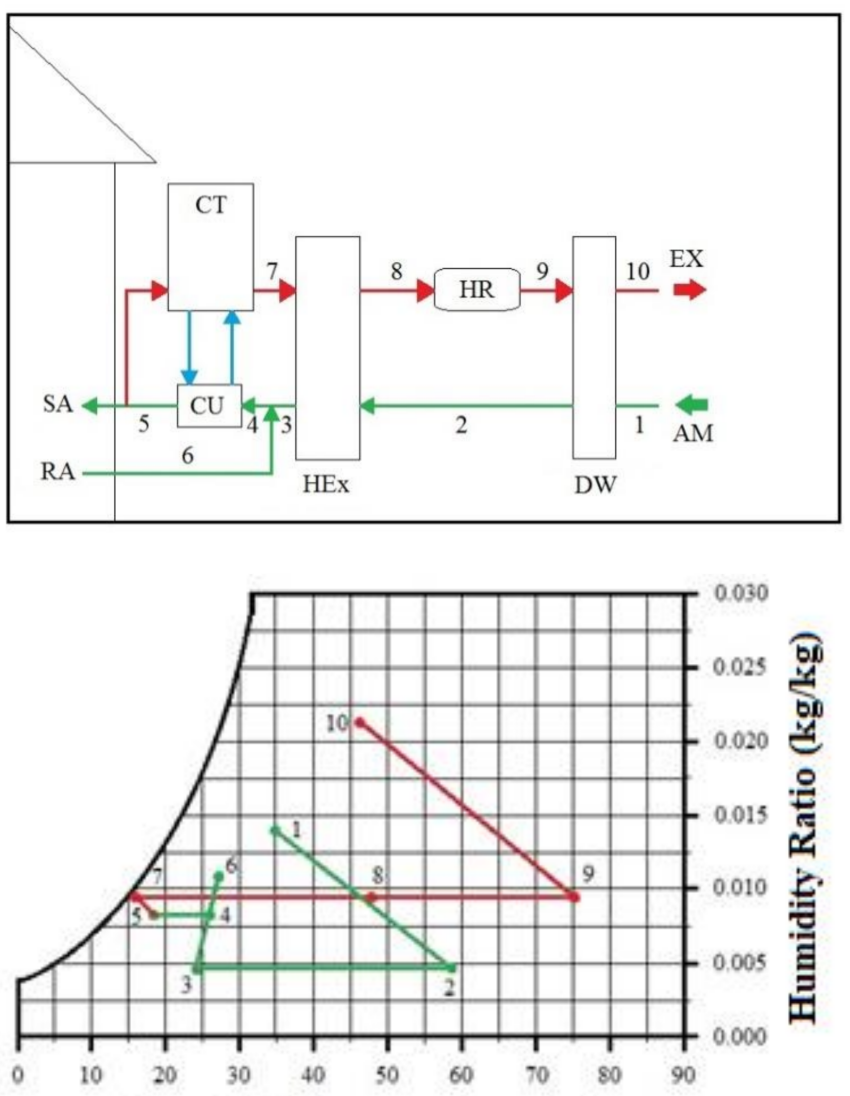

Dry Bulb Temperature $\left({ }^{\circ} \mathrm{C}\right)$

Figure 7. REVERS Cycle.

It is observed that it has lesser cooling effect than the SENS cycle, as the air enters the cooling coil with a relatively higher temperature than in SENS cycle. Thus, it requires less regeneration heat and produces a lesser cooling effect compared with the SENS cycle.

\subsection{DINC Cycle}

The direct-indirect evaporative cooling (DINC) cycle, as shown in Figure 8, was proposed by researchers at Texas A\&M University [36]. In this cycle, indirect cooling (IC) and evaporative cooling (EC) replace the cooling coil and cooling tower in the REVERS cycle. In addition, only IC is added to the modified ventilation cycle. 

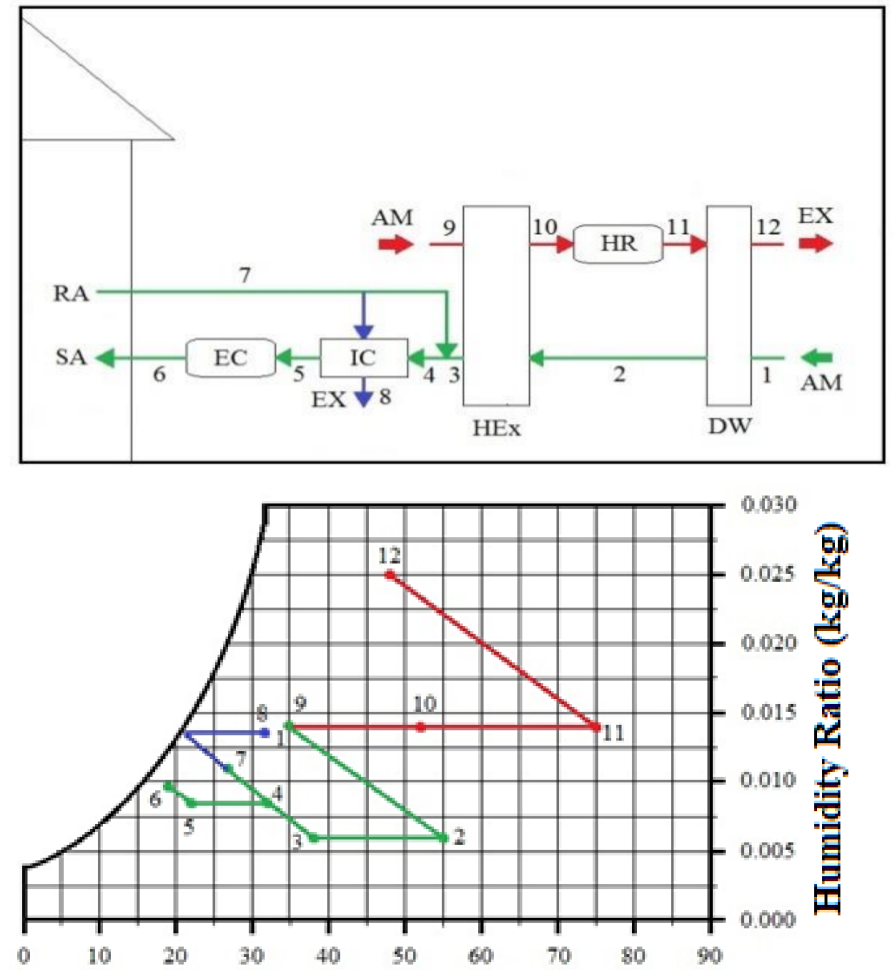

Dry Bulb Temperature $\left({ }^{\circ} \mathrm{C}\right)$

Figure 8. DINC Cycle.

\section{Use of Solar Energy for Rotary Desiccant Cooling System}

For regeneration of the desiccant wheel, a rotary desiccant-based cooling system needs hot air at moderate temperatures of about $60-80{ }^{\circ} \mathrm{C}$, which can be made available by using low-grade heat sources such as solar collectors, waste heat, geothermal sources, etc. Solar energy, with the advantages of neatness and sustainability, is commonly recognized as a hopeful source of low-grade thermal energy. The concept of using solar energy for cooling purposes is appropriate due to the phase that exists between cooling load and solar energy availability [37].

\subsection{Solar Collectors}

Solar collectors, which are the most important part of any solar-assisted system, is essentially a heat exchanger which converts solar energy into internal energy of a medium such as water, air or oil [38]. It absorbs solar energy and transfers this heat to a circulating transport medium. There are two types of collectors, namely nontracking and tracking solar collectors. Nontracking solar collectors are the most suitable collectors for desiccant cooling systems.

\subsection{Nontracking Solar Collectors}

Nontracking solar collectors are also called stationary collectors, as they are always fixed and unable to track the sun. Most widely used collectors such flat-plate type solar collectors, evacuated tube type solar collectors and compound parabolic type solar collectors, belong to this type of solar collector.

\subsubsection{Flat-Plate Solar Collectors (FPSCs)}

Flat-plate solar collectors are the most commonly used solar collectors in solar waterheating applications, where a temperature of about $30-80{ }^{\circ} \mathrm{C}$ is to be attained. A FPSC consists of an insulated metal box with a transparent top and a black colored plate absorber, which captures solar energy incident on it and transfers it to a transport media to increase 
its internal energy. The heated media can then be used for specific applications such as heating regeneration air. It is noted that flat-plate heat collectors play a very important role in utilizing solar energy for useful purposes [39]. These collectors are classified into two basic types on the basis of heat-transfer fluid [40]. Liquid type, in which water or a mixture of water and antifreeze oil is used as heat the transfer fluid, and Air type, in which air is used as the heat transfer fluid.

\subsubsection{Evacuated Tube Solar Collectors (ETSCs)}

An ETSC is made of parallel evacuated glass pipes [41]. Each evacuated glass pipe consists of one inner tube, which is layered with selective coating, and one outer tube, which is transparent. Both the tubes have nominal reflection properties. The sun rays which pass from the outer transparent tube are absorbed by the inner tube. As a result, the inner tube gets heated and with the help of a vacuum this heat is retained inside the inner tube. The vacuum also allows the solar radiation to pass through but does not permit heat to convect. ETSCs can be used at an operating temperature of $50-200{ }^{\circ} \mathrm{C}$ [42] ETSCs have more efficiency when compared with FPC, mainly under low temperatures with isolation [43]. Gao et al. [44] classified ETSCs into two types; the first one is singlewalled glass evacuated tube type and the second one is Dewar tube type. Badar et al. [45] developed a steady-state one-dimensional numerical model, that simulates the steady-state thermal performance of the vacuum tube solar collector and has coaxial piping with singleas well as two-phase flow.

Many researchers have studied ETSCs used in water heaters experimentally [46,47], analytically $[48,49]$. Other researchers have worked on applications of ETSCs in a wide variety of fields [50-68]. Mehta and Rane [69] investigated the liquid desiccant-based air-conditioning system which utilized solar energy with heat pipes as a liquid desiccant regenerator. They achieved an average thermal COP of 0.82 over an experiment period of $5 \mathrm{~h}$, with single stage regeneration and an isolation range of $509-752 \mathrm{~W} / \mathrm{m}^{2}$. Parasitic power consumption was less than $40 \mathrm{~W}$, which worked out to be $1.5 \%$ of the regeneration duty. Solar collector efficiency of $44.7 \%$ was obtained, along with production of distilled water at $5.14 \mathrm{~kg} / \mathrm{h}$ at regeneration temperature of $117^{\circ} \mathrm{C}$ with $719 \mathrm{~W} / \mathrm{m}^{2}$ global radiations.

\subsubsection{Compound Parabolic Solar Collector (CPSC)}

In 1960, Winston developed the CPSC, but in the USA its application for collecting solar energy was not started until 1974. CPSC is a non-imaging-type concentrating solar collector. The requirement of moving the concentrator to accommodate change in orientation of solar radiation can be minimized with the help of a trough having two segments of a parabola facing each other. A 2D-CPSC consists of an absorber plate placed in between two parabolic reflectors, and hence it is known as a compound parabolic collector, as shown in Figure 9. A CPSC can collect radiation arriving with large angular spread and can focus it onto an absorber at the center [70]. Here, the incident rays after reflection from the reflector are not focused on a point, but are merely collected on an absorber surface.

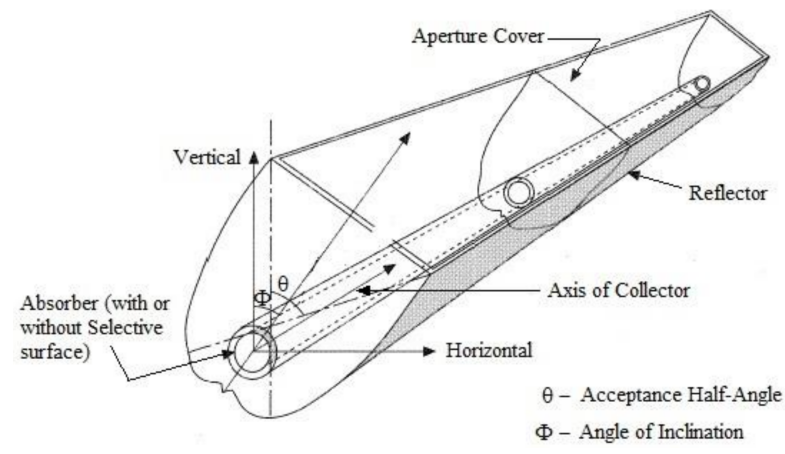

Figure 9. Compound Parabolic Collector. 


\section{Recent Advancements in the Field of Desiccant Cooling Systems}

Henning et al. [71] investigated different types of solar collector for collecting thermal energy and concluded that nontraching type solar collector are best for desiccant cooling system. Researchers in the UK have prepared a mathematical model for determining the performance of a hybrid solar-assisted desiccant dehumidification and cooling system (SADDCS) [72]. The feasibility study was conducted based on actual meteorological data in Europe during the summer [73,74]. The obtained results predicted that in the Atlantic, Central Europe, and also in South Europe, a single-stage rotary desiccant wheel air-conditioning system powered by solar energy was feasible. The results of the simulation regarding performance were evaluated based on the energy-saving ratio compared to a gas-powered rotary desiccant wheel air-conditioning system. It was noted that gas energy savings of $25.1-46.5 \%$ were found in different places, except in Oslo, which had a gas energy saving of $93 \%$ due to its low latent load compared to other locations.

Finocchiaro et al. [75] observed that because of the limited cooling capacity of the return air in a desiccant cooling system, the obtained outlet temperature was hardly lower than $26^{\circ} \mathrm{C}$. So, to avoid this problem, a packed wet heat exchanger was used as a replacement for the sensible heat exchanger for removal of more sensible load. An experimental setup was developed for studying the detailed performance of the proposed hybrid SADDCS. The results showed that with an optimized indirect evaporative cooling process, a supply temperature of $21-22{ }^{\circ} \mathrm{C}$ could be attained, without using a secondary cooling unit.

Baniyounes et al. $[76,77]$ performed experiments and studied theoretically the performance of hybrid SADDCS at Central Queensland University (Rock Hampton, Australia). In order to obtain the system performance, a simulation model was developed using TRNSYS software. It was observed that the solar-collector area affected the $\mathrm{COP}_{\mathrm{Th}}$, which increased with an increase in the solar-collector area when the area was less than $20 \mathrm{~m}^{2}$; but it barely changed when the area was beyond $20 \mathrm{~m}^{2}$, and the highest $\mathrm{COP}_{\mathrm{Th}}$ obtained was 1.2.

Fong et al. [78] implemented a hybrid SADDCS to condition spaces with high latent load in Hong Kong, such as restaurants and wet markets. A simulation model was developed in TRNSYS for studying its performance in terms of COP and energy-saving efficiency. In the simulation, the sensible and latent loads for the restaurant and the wet market were $19 \mathrm{~kW}, 13 \mathrm{~kW}$ and $27 \mathrm{~kW}, 13 \mathrm{~kW}$, respectively. The results clearly illustrated that the hybrid SADDCS was capable of maintaining indoor temperature and humidity ratio more gradually, when compared with conventional vapor-compression systems under different climatic conditions and loading in a year. The system was reported to obtain an annual energy saving ratio of $49.5 \%$ for the restaurant and $13.3 \%$ for the wet market, when the humidity in the designed zone was $60 \% \mathrm{RH}$. The energy-saving ratio decreased with an increase in RH of the designed zone. Therefore, this hybrid system was preferred in subtropical regions such as Hong Kong where latent load is high.

Khalid et al. [79] developed a hybrid SADDCS with two indirect evaporative coolers in place of direct evaporative coolers in Karachi, Pakistan. The indirect ECs were placed so that one was before the desiccant wheel, to precool the supply air, and the other was between the heat exchanger and the cooling coil of VCRS. Due to very high latent and sensible heat loads in Karachi, the hybrid system alone could not provide the air at comfort standards and an auxiliary VCRS was required. The indirect ECs saved energy by $15 \%$, due to decrease in regeneration temperature.

Hurdogan et al. [80] investigated a hybrid SADDCS, in which three parallel working air groups were present, as shown in Figure 10. The system was supplied with $100 \%$ fresh air as process air, ambient air was regeneration air, and the return air was utilized for the recovery of heat from process air before it is exhausted outdoors.

The system used four heat exchangers for the recovery of heat from the regeneration air and to achieve low process air temperature. The main aim of the research, carried out both experimentally and by simulation, was to find out the efficiency of solar energy utilization. As per the atmospheric dry bulb temperature and solar radiation in Adana, 
Turkey, the regeneration temperature was increased by $5-17^{\circ} \mathrm{C}$, SF in regeneration heat was $45-140 \%$ and $\mathrm{COP}_{\mathrm{Tot}, \mathrm{HS}}$ achieved was between 50 and $120 \%$.

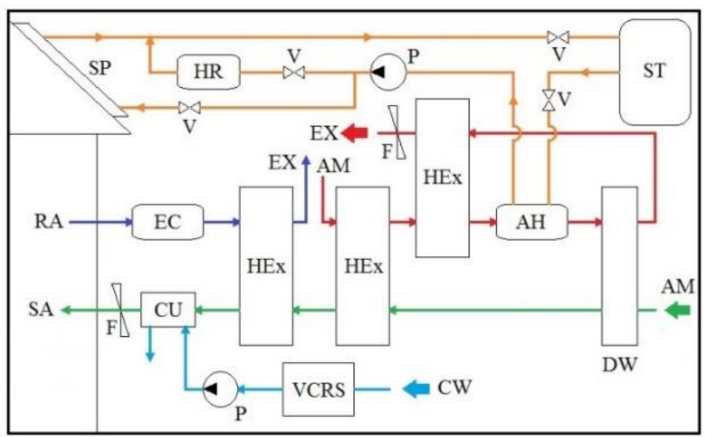

Figure 10. Schematic diagram of Hybrid SDEC and VCRS.

La et al. [81] worked with an air-conditioning system consisting of a two-stage hybrid desiccant air-conditioning unit and vapor-compression refrigeration system in parallel, along with a flat-plate solar collector, as shown in Figure 11. Here, the supply air consisted of two streams, one from TSDCS as dehumidified air and other from VCRS as cooled air. Thus, the latent heat load was handled by the solar-powered TSDCS and the sensible heat load was handled by the conventional VCRS. The experimental investigation of this system, powered by $72 \mathrm{~m}^{2}$ solar collector, was performed at local Chinese summer conditions. The intensity of solar radiant varied from $122.2 \mathrm{~W} / \mathrm{m}^{2}$ to $539.9 \mathrm{~W} / \mathrm{m}^{2}$ and the average efficiency of the solar collector was 0.32 , when the temperature and humidity ratio of atmospheric air were $34.6{ }^{\circ} \mathrm{C}$ and $21.54 \mathrm{~g} / \mathrm{kg}$, respectively. The results showed that the solar TSDCS could achieve $\mathrm{COP}_{\mathrm{Th}}$ and $\mathrm{COP}_{\mathrm{El}}$ of 1.24 and 11.48, correspondingly, with an average cooling capacity of $10.9 \mathrm{~kW}$. In the integrated hybrid system, $35.7 \%$ of the output was due to the solar TSDCS unit, and the $\mathrm{COP}_{\mathrm{El}}$ of the whole system was 4.41 , which was $35 \%$ higher than VCRS.

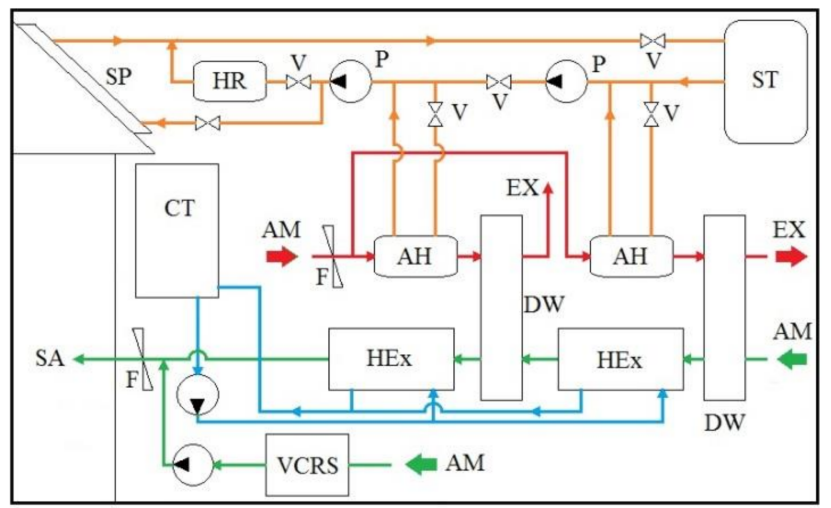

Figure 11. Schematic diagram of Solar hybrid desiccant air-conditioning system.

Jose et al. [82] investigated the performance of a hybrid SADDCS for conditioning a space with a radiant floor system, as shown in Figure 12. This system was modelled in TRNSYS 16, and the performance of the system was tested assuming that the radiant floor in the room kept the floor temperature at $2{ }^{\circ} \mathrm{C}$ above that of the wet bulb temperature of the conditioned space, and the hybrid system was capable of handling latent and sensible loads. The performance was carried out under two weather conditions, both in hot weather, but one with humid air and the other with dry air. The results showed that the desiccant system alone was feasible in hot and humid weather conditions, and the entire combined system saved $35 \%$ electricity compared to that of a conventional system. 


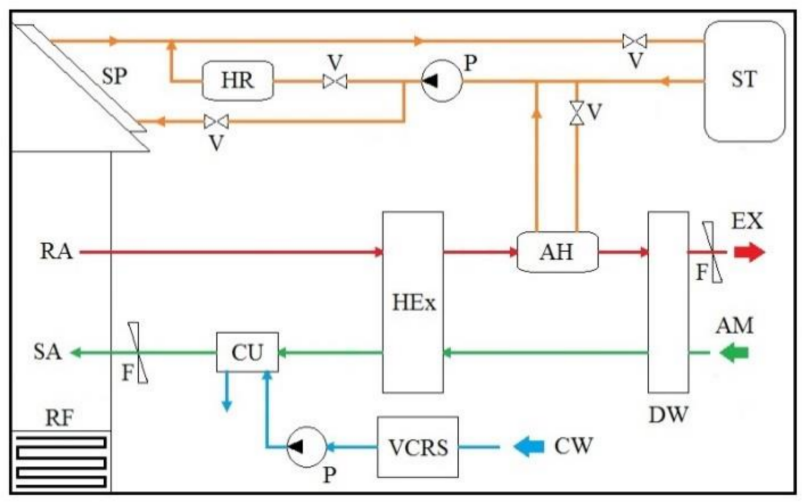

Figure 12. Schematic of Solar desiccant cooling system with radiant floor.

Beccali et al. [83] investigated a hybrid SADDCS for conditioning a space having a radiant ceiling in place of a radiant floor, as shown in Figure 13.

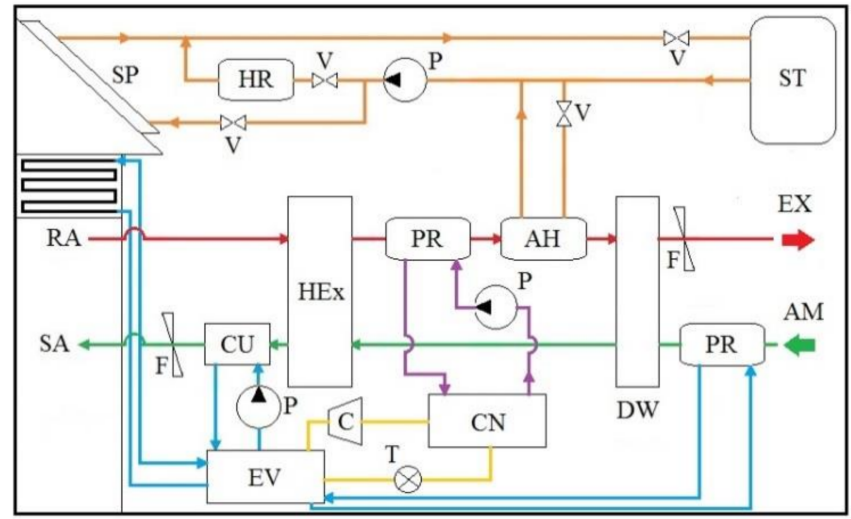

Figure 13. Schematic of Solar desiccant cooling system with radiant ceiling.

In this system, chilled water from a VCR system was used in three ways: one fraction was supplied to the cooling coil placed before the desiccant wheel to precool the supply air, another fraction was supplied to the cooling coil placed after the sensible heat exchanger to remove more sensible load from the supply air, and the last fraction was supplied to the radiant ceiling. The heat rejected from the chiller was utilized for the preheating of the regeneration air before being heated in the solar heater. The experiments were carried out in both summer and winter conditions. The supply temperature and $\mathrm{COP}_{\mathrm{El}, \mathrm{HS}}$ for summer conditions were reported to be $24-26^{\circ} \mathrm{C}$ and 1.94 , respectively, and those for winter conditions were $16-20^{\circ} \mathrm{C}$ and 6 , respectively. It was also reported that the solar collector area can be reduced by $30 \%$, due to the diversion of heat rejected by the chiller for the preheating of regeneration air.

\section{Recent Applications of Solar-Assisted Desiccant Dehumidification and Cooling System}

Since the 1980s, the industrial market for desiccant cooling systems has been well developed [84] and the commercial application of this technology has increased significantly during recent decades. For more than five decades, researchers have been working on making this technology provide more comfort and flexibility, with better control and reduced global energy consumption, while addressing environmental issues [85,86]. As this system involves large amounts of low-grade heat, the use of solar energy as the heat source is more economical, since solar energy is available abundantly. Applications of this desiccant cooling system are increasing rapidly, and some of them are detailed below. 


\subsection{Solar Driven Rotary Hybrid Desiccant Air-Conditioning Systems}

A SADDCS, manufactured by ATECNIC, an air-conditioning equipment manufacturer, is installed in Sintra, Portugal under a project funded by EU's THERMIE program [87-89]. In this system, a nozzle-type humidifier and heat-recovery wheel are used for the precooling and humidification of the process air, and a humidifier is installed on the regeneration side to humidify the return air. The system is powered with the help of a compound parabolic collector with an area of $75 \mathrm{~m}^{2}$, and is also coupled to a $3 \mathrm{~m}^{3}$ buffer tank through a plate heat exchanger, and works with a maximum cooling power of $75 \mathrm{~kW}$, maximum electrical load of $15 \mathrm{~kW}$ and operates with variable air flow, the maximum of which is $9600 \mathrm{~m}^{3} / \mathrm{h}$. According to the design considerations, the estimated COP of the system is 0.78 and the estimated SF for heating and cooling are $70 \%$.

A SADDCS has been developed at the University of Palermo, Italy, which is associated with $22.5 \mathrm{~m}^{2}$ flat-plate solar collectors and is integrated with a $76.1 \mathrm{~m}^{2}$ radiant ceiling [90]. This system is equipped with a hot-water tank, auxiliary boiler, and a back-up water-to-air chiller integrated with and air treatment process and two cooling coils, before and after the desiccant wheel, for precooling and pre-dehumidification of process air. This system was operational under a peak summer load condition of $28.8 \mathrm{~kW}$ with an estimated thermal COP of 0.86 .

Recently, in Italy, a hybrid SADDCS which is associated with photovoltaic thermal collectors, a gas-powered CHP tri-generation system and a reversible heat pump and is connected to the electrical grid of the building, has been installed [91,92]. It works on the idea of the removal of waste heat from PV cells, and the parallel utilization of that heat through the convective air flow behind photovoltaic panels. These PV cells produce the electricity required for the heat pump and for domestic use, whereas the convective air flow under the PV panels cools the PV cells and recuperates the captured solar energy, which is used for the conditioning of a kitchen.

The International Energy Agency under the Solar Heating and Cooling Programme installed five rotary desiccant dehumidification and cooling systems, within Task 25 of "Solar Assisted Air Conditioning of Buildings" at Waalwijk (Netherlands), Mataro (Spain), Hartberg (Austria), Lisbon (Portugal) and Freiburg (Germany), respectively [93,94]. The design cooling capacities of the five systems are, $22 \mathrm{~kW}, 55 \mathrm{~kW}, 30 \mathrm{~kW}, 36 \mathrm{~kW}$ and $50 \mathrm{~kW}$, respectively.

The Freiburg plant has been planned as a solar, self-sufficient system powered by a $100 \mathrm{~m}^{2}$ solar air-collector system without any backup thermal storage, whereas the Hartberg plant uses evacuated tube collectors of $12 \mathrm{~m}^{2}$ surface area. The Mataro plant is powered by a combined solar thermal energy system consisting of both $105 \mathrm{~m}^{2}$ solar air collectors and a PV solar air-preheating system. The Lisbon plant is integrated with a heat pump and is powered by $51 \mathrm{~m}^{2}$ compound parabolic collectors.

\subsection{Use of Rotary Hybrid Desiccant Cooling for Preservation Purpose}

Other than comfort air-conditioning, the desiccant cooling is also preferred for preserving different items in warehouses and supermarkets. Thorpe et al. [95] proposed a desiccant cooling system, regenerated with the help of solar energy and used for preserving grains. This system was capable of generating cooling at up to 50 times the electrical energy consumption.

\section{Conclusions}

Rotary desiccant-based air-conditioning systems are open heat-driven hybrid systems which combine different technologies such as desiccant dehumidification, evaporative cooling, refrigeration, and regeneration. Being heat-driven, rotary desiccant air-conditioning systems have the chance to use low-grade thermal energy obtained from the sun. In this paper the basic principles and recent research developments and challenges related to rotary desiccant cooling systems are recalled and their applications and importance are summarized. It is shown that with novel system configurations and new desiccant ma- 
terials there is great potential for improving the performance and consistency of rotary desiccant systems. At the same time, the use of solar energy for regeneration purposes can minimize the operating cost to a great extent. Some examples are presented to demonstrate how the rotary desiccant air conditioning can be a promising solution for traditional vaporcompression air-conditioning systems. Recent advances and ongoing research related to solar-powered hybrid rotary desiccant cooling systems are also summarized. One of the main challenges for solar energy is how to realize the sustainable operation of solar desiccant wheel air-conditioning systems, because solar energy is not steady. Most of the present research works concentrate on solar energy with auxiliary electrical heaters, to solve this intermittent problem. Solar hybrid desiccant cooling systems using energy storage can provide a promising solution. The availability of advanced desiccant materials with high adsorbability and low regeneration temperature, the reduction in capital cost and size of the system, improvements in energy consumption rate, and standardization of system design are the other challenges faced by rotary desiccant air-conditioning systems.

1. It has been seen that a vapor-compression system is commonly implemented in these hybrid systems. Although these hybrids systems consume both solar energy and electricity, significant electrical power savings can be obtained compared to conventional vapor-compression systems, due to the optimal use of solar energy. According to the above literature, to eliminate the obstacles in the path of environmentally friendly desiccant air-conditioning further suggestions can be summarized as follows.

2. To take a step forward, more concentrated studies on the development and evaluation of advanced desiccant materials are still required.

3. Development of multistage dehumidification systems with staged regeneration, to reduce required reactivation temperature and to increase thermal utilization rate.

4. One method to decrease the large size and / or number of solar collectors necessary for heating the regeneration air, is to use condenser heat to increase the temperature of the regeneration air and then transfer it through the collectors. In this arrangement, the cooling effect of the air-conditioning system can be used to bring the air within the comfort conditions.

5. Determination of the best operating approaches to improve system applicability under various seasons, weather and locations.

6. Small and compact system designs in order to achieve a hybrid desiccant air-conditioning system that can be extended to small offices and residential buildings, thus decreasing building energy consumption.

While significant progress has been made in the development of new, advanced desiccant materials and in the efficiency and cost effectiveness of the equipment used in solar-assisted rotary desiccant air-conditioning systems, this technology has received much less recognition by the air-conditioning industry. Only a few commercial systems and designs are available, with specific applications such as warehouses and supermarkets. Technology transfer, standardization of system design and production processes, minimizing costs, improvements in the system efficiency and reduction in size are necessary for rotary desiccant air-conditioning technology in order to achieve extensive application into the commercial air-conditioning market.

Author Contributions: Writing—review and editing, R.P.S.; supervision—R.K.D. Both authors have read and agreed to the published version of the manuscript.

Funding: This research received no external funding.

Institutional Review Board Statement: Not applicable.

Informed Consent Statement: Not applicable.

Data Availability Statement: This study did not report any data.

Conflicts of Interest: The authors declare no conflict of interest. 


\section{Abbreviations}

\begin{tabular}{|c|c|}
\hline $\mathrm{AH}$ & Air Heater \\
\hline $\mathrm{AM}$ & Ambient \\
\hline $\mathrm{C}$ & Compressor \\
\hline $\mathrm{CHP}$ & Combined Heat and Power \\
\hline $\mathrm{CN}$ & Condenser \\
\hline $\mathrm{COP}$ & Coefficient of Performance \\
\hline $\mathrm{COP}_{\mathrm{Th}}$ & Coefficient of Performance (based on thermal consumption) \\
\hline $\mathrm{COP}_{\text {Tot,HS }}$ & Coefficient of Performance (based on total energy consumption/Hybrid system) \\
\hline $\mathrm{COP}_{\mathrm{El}}$ & Coefficient of Performance (based on electrical consumption) \\
\hline $\mathrm{COP}_{\mathrm{El}, \mathrm{HS}}$ & Coefficient of Performance(based on electrical consumption/Hybrid system) \\
\hline CPSC & Compound Parabolic Solar Collector \\
\hline $\mathrm{CT}$ & Cooling Tower \\
\hline $\mathrm{CU}$ & Cooling Unit \\
\hline $\mathrm{CW}$ & Cooling Water \\
\hline DBT & Dry Bulb Temperature \\
\hline DDCS & Desiccant Dehumidification and Cooling Systems \\
\hline DW & Desiccant Wheel \\
\hline $\mathrm{EC}$ & Evaporative Cooling \\
\hline ETSCs & Evacuated Tube Solar Collectors \\
\hline $\mathrm{EV}$ & Evaporator \\
\hline EX & Exhaust \\
\hline $\mathrm{F}$ & Fan \\
\hline FPSCs & Flat-Plate Solar Collectors \\
\hline HEx & Heat Exchanger \\
\hline HR & Heater \\
\hline HVAC & Heating, Ventilating and Air-Conditioning \\
\hline IC & Indirect Cooling \\
\hline $\mathrm{P}$ & Pump \\
\hline PR & Preheater \\
\hline PV & Photo Voltaic \\
\hline RA & Return Air \\
\hline $\mathrm{RC}$ & Radiant Ceiling \\
\hline RF & Radiant Floor \\
\hline $\mathrm{RH}$ & Relative Humidity \\
\hline SADDCS & Solar-Assisted Desiccant Dehumidification and Cooling System \\
\hline SA & Supply Air \\
\hline SF & Solar Fraction \\
\hline SJTU & Shanghai Jiao Tong University \\
\hline SP & Solar Panels \\
\hline ST & Storage Tank \\
\hline $\mathrm{T}$ & Throttle valve \\
\hline TSDCS & Two-stage Desiccant Cooling System \\
\hline $\mathrm{V}$ & Valve \\
\hline VAC & Vapor Absorption Cooling \\
\hline $\mathrm{VC}$ & Vapor Compression \\
\hline VCRS & Vapor-Compression Refrigeration System \\
\hline
\end{tabular}

\section{References}

1. Wrobel, J.; Walter, P.S.; Schmitz, G. Performance of a solar assisted air conditioning system at different locations. Sol. Energy 2013, 92, 69-83. [CrossRef]

2. Wang, S.K. Handbook of Air Conditioning and Refrigeration; McGraw-Hill: New York, NY, USA, 2001.

3. Subramanyam, N.; Maiya, M.; Murthy, S. Parametric studies on a desiccant assisted air-conditioner. Appl. Therm. Eng. 2004, 24, 2679-2688. [CrossRef]

4. Dhar, P.; Singh, S. Studies on solid desiccant based hybrid air-conditioning systems. Appl. Therm. Eng. 2001, 21, 119-134. [CrossRef] 
5. Zhang, L.; Dang, C.; Hihara, E. Performance analysis of a no-frost hybrid air conditioning system with integrated liquid desiccant dehumidification. Int. J. Refrig. 2010, 33, 116-124. [CrossRef]

6. Daou, K.; Wang, R.Z.; Xia, Z.Z. Desiccant cooling air conditioning: A review. Renew. Sustain. Energy Rev. 2006, 10, 55-77. [CrossRef]

7. La, D.; Dai, Y.; Li, Y.; Wang, R.; Ge, T. Technical development of rotary desiccant dehumidification and air conditioning: A review. Renew. Sustain. Energy Rev. 2010, 14, 130-147. [CrossRef]

8. Zhang, L.Z.; Niu, J.L. A pre-cooling Munters environmental control desiccant cooling cycle in combination with chilled-ceiling panels. Energy 2003, 28, 275-292. [CrossRef]

9. Ge, T.S.; Dai, Y.J.; Wang, R.Z. Review on solar powered rotary desiccant wheel cooling system. Renew. Sustain. Energy Rev. 2014, 39, 476-497. [CrossRef]

10. Lu, Z.; Wang, R.; Xia, Z. Experimental analysis of an adsorption air conditioning with micro-porous silica gel-water. Appl. Therm. Eng. 2013, 50, 1015-1020. [CrossRef]

11. Liu, Y.; Wang, R.; Xia, Z. Experimental performance of a silica gel-water adsorption chiller. Appl. Therm. Eng. 2005, 25, 359-375. [CrossRef]

12. Alam, K.C.A.; Saha, B.B.; Kang, Y.T. Heat exchanger design effect on the system performance of silica gel adsorption refriger-ation systems. Int. J. Heat Mass Transf. 2000, 43, 4419-4431. [CrossRef]

13. Enteria, N.; Yoshino, H.; Mochida, A.; Satake, A.; Yoshie, R.; Takaki, R.; Yonekura, H.; Mitamura, T.; Tanaka, Y. Performance of solar-desiccant cooling system with Silica-Gel $\left(\mathrm{SiO}_{2}\right)$ and Titanium Dioxide $\left(\mathrm{TiO}_{2}\right)$ desiccant wheel applied in East Asian climates. Sol. Energy 2012, 86, 1261-1279. [CrossRef]

14. $\mathrm{Wu}, \mathrm{J} . ; \mathrm{Li}, \mathrm{S}$. Study on cyclic characteristics of silica gel-water adsorption cooling system driven by variable heat source. Energy 2009, 34, 1955-1962. [CrossRef]

15. Srivastava, N.C.; Eames, I.W. A review of adsorbents and adsorbates in solid-vapour adsorption heat pump systems. Appl. Therm. Eng. 1998, 18, 707-714. [CrossRef]

16. Pramuang, S.; Exell, R. The regeneration of silica gel desiccant by air from a solar heater with a compound parabolic concentrator. Renew. Energy 2007, 32, 173-182. [CrossRef]

17. Chung, T.-W.; Chung, C.-C. Increase in the amount of adsorption on modified silica gel by using neutron flux irradiation. Chem. Eng. Sci. 1998, 53, 2967-2972. [CrossRef]

18. Abd-Elrahman, W.; Hamed, A.; El-Emam, S.; Awad, M. Experimental investigation on the performance of radial flow desiccant bed using activated alumina. Appl. Therm. Eng. 2011, 31, 2709-2715. [CrossRef]

19. Hamed, A.; Abd-Elrahman, W.; El-Emam, S.; Awad, M. Theoretical and experimental investigation on the transient coupled heat and mass transfer in a radial flow desiccant packed bed. Energy Convers. Manag. 2013, 65, 262-271. [CrossRef]

20. Karamanis, D.; Vardoulakis, E. Application of zeolitic materials prepared from fly ash to water vapor adsorption for solar cooling. Appl. Energy 2012, 97, 334-339. [CrossRef]

21. Rao, Z.; Wang, S.; Zhang, Z. Energy saving latent heat storage and environmental friendly humidity-controlled materials for indoor climate. Renew. Sustain. Energy Rev. 2012, 16, 3136-3145. [CrossRef]

22. Kubota, M.; Hanada, T.; Yabe, S.; Matsuda, H. Regeneration characteristics of desiccant rotor with microwave and hot-air heating. Appl. Therm. Eng. 2013, 50, 1576-1581. [CrossRef]

23. Kubota, M.; Hanada, T.; Yabe, S.; Kuchar, D.; Matsuda, H. Water desorption behavior of desiccant rotor under microwave irradiation. Appl. Therm. Eng. 2011, 31, 1482-1486. [CrossRef]

24. White, S.D.; Goldsworthy, M.; Reece, R.; Spillmann, T.; Gorur, A.; Lee, D.Y. Characterization of desiccant wheels with alternative materials at low regeneration tempera-tures. Int. J. Refrig. 2011, 34, 1786-1791. [CrossRef]

25. Beery, E.K.; Ladisch, M.R. Chemistry and properties of starch based desiccants. Enzym. Microb. Technol. 2001, $28,573-581$. [CrossRef]

26. Jia, C.; Dai, Y.; Wu, J.; Wang, R. Experimental comparison of two honeycombed desiccant wheels fabricated with silica gel and composite desiccant material. Energy Convers. Manag. 2006, 47, 2523-2534. [CrossRef]

27. Pennington, N.A. Humidity Changer for Air Conditioning. U.S. Patent 2,700,537, 25 January 1955.

28. Löf, G.O.G.; Cler, G.; Brisbane, T. Performance of a Solar Desiccant Cooling System. J. Sol. Energy Eng. 1988, 110, 165-171. [CrossRef]

29. Kanoğlu, M.; Bolattürk, A.; Altuntop, N. Effect of ambient conditions on the first and second law performance of an open desiccant cooling process. Renew. Energy 2007, 32, 931-946. [CrossRef]

30. Bourdoukan, P.; Wurtz, E.; Joubert, P. Comparison between the conventional and recirculation modes in desiccant cooling cycles and deriving critical efficiencies of components. Energy 2010, 35, 1057-1067. [CrossRef]

31. Waugaman, D.G.; Kini, A.; Kettleborough, C.F. A Review of Desiccant Cooling Systems. J. Energy Resour. Technol. 1993, 115, 1-8. [CrossRef]

32. Dunkle, R.V. A method of solar air conditioning. Mech. Chem. Eng. Trans. Inst. Eng. 1965, 73, 73-78.

33. Maclaine-Cross, I.L. A Theory of Combined Heat and Mass Transfer in Regenerations. Ph.D. Thesis, Monash University, Clayton, Australia, 1974.

34. Kang, T.S. Adiabatic Desiccant Open Cooling Cycles. Master's Thesis, University of New South Wales, Sidney, Australia, April 1985. 
35. Maclaine-Cross, I.L. High-Performance Adiabatic Desiccant Open-Cooling Cycles. J. Sol. Energy Eng. 1985, 107, 102-104. [CrossRef]

36. Waugaman, D.G.; Kettleborough, C.F. Combining direct and indirect evaporative cooling with a rotating desiccant wheel in residential applications. In Proceedings of the ASME International Thermal and Solar Energy Conference, Honolulu, HI, USA, 22-27 March 1987.

37. Pesaran, A.A.; Wipke, K. Desiccant Cooling Using Unglazed Transpired Solar Collectors; NREL/TP-432-4827; National Renewable Energy Laboratory: Golden, CO, USA, 1992.

38. Soteris, A.K. Solar thermal collectors and applications. Prog. Energy Combust. Sci. 2004, 30, 231-295.

39. Xu, X.; Yang, L.; Zhang, X.; Peng, D. Review on the Development of Flat-Plate Solar Collector and its Building-Integrated Designing. In Proceedings of ISES World Congress 2007 (Vol. I-Vol. V); Springer: Berlin/Heidelberg, Germany, 2008 ; pp. $623-626$.

40. Goswami, D.Y. Principles of Solar Engineering, 3rd ed.; CRC Press: Boca Raton, FL, USA, 2015; pp. 127-129.

41. Soteris, A.K. Solar Energy Engineering: Processes Systems; Academic Press: Cambridge, MA, USA, $2014 ;$ p. 125.

42. Tyagi, V.V.; Kaushik, S.C.; Tyagi, S.K. Advancement in solar photovoltaic/thermal (PV/T) hybrid collector technology. Renew. Sustain. Energy Rev. 2012, 16, 1383-1398. [CrossRef]

43. Morrison, G.; Budihardjo, I.; Behnia, M. Water-in-glass evacuated tube solar water heaters. Sol. Energy 2004, 76, 135-140. [CrossRef]

44. Gao, Y.; Zhang, Q.; Fan, R.; Lin, X.; Yu, Y. Effects of thermal mass and flow rate on forced-circulation solar hot-water system: Comparison of water-in-glass and U-pipe evacuated-tube solar collectors. Sol. Energy 2013, 98, 290-301. [CrossRef]

45. Badar, A.W.; Buchholz, R.; Ziegler, F. Single and two-phase flow modeling and analysis of a coaxial vacuum tube solar collector. Sol. Energy 2012, 86, 175-189. [CrossRef]

46. Hazami, M.; Kooli, S.; Naili, N.; Farhat, A. Long-term performances prediction of an evacuated tube solar water heating system used for single-family households under typical Nord-African climate (Tunisia). Sol. Energy 2013, 94, 283-298. [CrossRef]

47. Yamaguchi, H.; Sawada, N.; Suzuki, H.; Ueda, H.; Zhang, X.R. Preliminary Study on a Solar Water Heater Using Supercritical Carbon Dioxide as Working Fluid. J. Sol. Energy Eng. 2010, 132, 11010. [CrossRef]

48. Ma, L.; Lu, Z.; Zhang, J.; Liang, R. Thermal performance analysis of the glass evacuated tube solar collector with U-tube. Build. Environ. 2010, 45, 1959-1967. [CrossRef]

49. Ayompe, L.; Duffy, A. Thermal performance analysis of a solar water heating system with heat pipe evacuated tube collector using data from a field trial. Sol. Energy 2013, 90, 17-28. [CrossRef]

50. Hayek, M.; Assaf, J.; Lteif, W. Experimental Investigation of the Performance of Evacuated-Tube Solar Collectors under Eastern Mediterranean Climatic Conditions. Energy Procedia 2011, 6, 618-626. [CrossRef]

51. Xu, L.; Wang, Z.; Yuan, G.; Li, X.; Ruan, Y. A new dynamic test method for thermal performance of all-glass evacuated solar air collectors. Sol. Energy 2012, 86, 1222-1231. [CrossRef]

52. Tang, R.; Yang, Y.; Gao, W. Comparative studies on thermal performance of waterin-glass evacuated tube solar water heaters with different collector tilt-angles. Sol. Energy 2011, 85, 1381-1389. [CrossRef]

53. Nkwetta, D.N.; Smyth, M.; Zacharopoulos, A.; Hyde, T. In-door experimental analysis of concentrated and non-concentrated evacuated tube heat pipe collectors for medium temperature applications. Energy Build. 2012, 47, 674-681. [CrossRef]

54. Budihardjo, I.; Morrison, G.L. Performance Model for Water-in-Glass Evacuated Tube Solar Water Heaters. In Proceedings of ISES World Congress 2007 (Vol. I-Vol. V); Springer: Berlin/Heidelberg, Germany, 2008; Volume 83, pp. 49-56. [CrossRef]

55. Nkwetta, D.N.; Smyth, M.; Zacharopoulos, A.; Hyde, T. Experimental field evaluation of novel concentrator augmented solar collectors for medium temperature applications. Appl. Therm. Eng. 2013, 51, 1282-1289. [CrossRef]

56. Sharma, S.; Iwata, T.; Kitano, H.; Sagara, K. Thermal performance of a solar cooker based on an evacuated tube solar collector with a PCM storage unit. Sol. Energy 2005, 78, 416-426. [CrossRef]

57. Sharma, N.; Diaz, G. Performance model of a novel evacuated-tube solar collector based on mini channels. Sol. Energy 2011, 85, 881-890. [CrossRef]

58. Kumar, R.; Adhikari, R.; Garg, H.; Kumar, A. Thermal performance of a solar pressure cooker based on evacuated tube solar collector. Appl. Therm. Eng. 2001, 21, 1699-1706. [CrossRef]

59. Madduri, A.; Loeder, D.; Beutler, N.; He, M.; Sanders, S. Concentrated evacuated tubes for solar-thermal energy generation using stirling engine. In Proceedings of the 2012 IEEE Energytech, Cleveland, OH, USA, 29-31 May 2012; pp. 1-6.

60. Çağlar, A.; Yamalı, C. Performance analysis of a solar-assisted heat pump with an evacuated tubular collector for domestic heating. Energy Build. 2012, 54, 22-28. [CrossRef]

61. Liang, R.; Ma, L.; Zhang, J.; Zhao, D. Theoretical and experimental investigation of the filled-type evacuated tube solar collector with U tube. Sol. Energy 2011, 85, 1735-1744. [CrossRef]

62. Kumar, A.; Kumar, S.; Nagar, U.; Yadav, A. Experimental Study of Thermal Performance of One-Ended Evacuated Tubes for Producing Hot Air. J. Sol. Energy 2013, 2013, 524715. [CrossRef]

63. Lamnatou, C.; Papanicolaou, E.; Belessiotis, V.; Kyriakis, N. Experimental investigation and thermodynamic performance analysis of a solar dryer using an evacuated-tube air collector. Appl. Energy 2012, 94, 232-243. [CrossRef]

64. Hayek, M. Investigation of evacuated-tube solar collectors performance using computational fluid dynamics. In Proceedings of the 2009 International Conference on Advances in Computational Tools for Engineering Applications, Beirut, Lebanon, 15-17 July 2009; pp. 240-244. 
65. Gao, J.; Ge, X. The study of solar heat pump with all-glass evacuated tube. In Proceedings of the 2009 International Conference on Electrical Machines and Systems, Tokyo, Japan, 15-18 November 2009; pp. 1-4.

66. Zambolin, E.; Del Col, D. Experimental analysis of thermal performance of flat plate and evacuated tube solar collectors in sta-tionary standard and daily conditions. Sol. Energy 2010, 84, 1382-1396. [CrossRef]

67. Kim, Y.; Han, G.; Seo, T. An evaluation on thermal performance of CPC solar collector. Int. Commun. Heat Mass Transf. 2008, 35, 446-457. [CrossRef]

68. Tang, R.; Gao, W.; Yu, Y.; Chen, H. Optimal tilt-angles of all-glass evacuated tube solar collectors. Energy 2009, $34,1387-1395$. [CrossRef]

69. Mehta, J.; Rane, M. Liquid Desiccant based Solar Air Conditioning System with Novel Evacuated Tube Collector as Regenerator. Procedia Eng. 2013, 51, 688-693. [CrossRef]

70. Senthilkumar, S.; Yasodha, N. Design and Development of a Three Dimensional Compound Parabolic Concentrator and Study of Optical and Thermal Performance. Int. J. Energy Sci. 2012, 2, 64-68.

71. Henning, H.M.; Erpenbeck, T.; Hindenburg, C.; Santamaria, I.S. The potential of solar energy use in desiccant cooling cycles. Int. J. Refrig. 2001, 24, 220-229. [CrossRef]

72. Beggs, C.B.; Sleigh, P.A.; Halliday, S.P. Solar desiccant cooling model. DETR Seminar (Desiccant and Solar Desiccant Systems). In Proceedings of the CIBSE National Conference, London, UK, 6 April 2000.

73. Mavroudaki, P.; Beggs, C.; Sleigh, A.; Halliday, S. The potential for solar powered single-stage desiccant cooling in southern Europe. Appl. Therm. Eng. 2002, 22, 1129-1140. [CrossRef]

74. Halliday, S.; Beggs, C.; Sleigh, P. The use of solar desiccant cooling in the UK: A feasibility study. Appl. Therm. Eng. 2002, 22, 1327-1338. [CrossRef]

75. Finocchiaro, P.; Beccali, M.; Nocke, B. Advanced solar assisted desiccant and evaporative cooling system equipped with wet heat exchangers. Sol. Energy 2012, 86, 608-618. [CrossRef]

76. Baniyounes, A.M.; Rasul, M.G.; Khan, M.M.K. Experimental assessment of a solar desiccant cooling system for an institutional building in sub-tropical Queens-Land, Australia. Energy Build 2013, 62, 78-86. [CrossRef]

77. Baniyounes, A.M.; Liu, G.; Rasul, M.; Khan, M. Analysis of solar desiccant cooling system for an institutional building in subtropical Queensland, Australia. Renew. Sustain. Energy Rev. 2012, 16, 6423-6431. [CrossRef]

78. Fong, K.; Lee, C.; Chow, T.; Fong, A. Investigation on solar hybrid desiccant cooling system for commercial premises with high latent cooling load in subtropical Hong Kong. Appl. Therm. Eng. 2011, 31, 3393-3401. [CrossRef]

79. Khalid, A.; Mahmood, M.; Asif, M.; Muneer, T. Solar assisted, pre-cooled hybrid desiccant cooling system for Pakistan. Renew. Energy 2009, 34, 151-157. [CrossRef]

80. Hürdoğan, E.; Büyükalaca, O.; Yılmaz, T.; Hepbasli, A.; Uçkan, I. Investigation of solar energy utilization in a novel desiccant based air conditioning system. Energy Build. 2012, 55, 757-764. [CrossRef]

81. La, D.; Dai, Y.J.; Li, Y.; Ge, T.S.; Wang, R.Z. Case study and theoretical analysis of a solar driven two-stage rotary desiccant cooling system assisted by vapour compression air-conditioning. Sol. Energy 2011, 85, 2997-3009. [CrossRef]

82. José, M.C.L.; Francisco, F.H.; Fernando, D.M.; Antonio, C.A. The optimization of the operation of a solar desiccant air handling unit coupled with a radiant floor. Energy Build 2013, 62, 427-435.

83. Marco, B.; Pietro, F.; Bettina, N. Energy performance evaluation of a demo solar desiccant cooling system with heat recovery for the regeneration of the adsorption material. Renew Energy 2012, 44, 40-52.

84. Wurm, J.; Kosar, D.; Clemens, T. Solid desiccant technology review. Bull. Int. Inst. Refrig. 2002, 82, $2-31$.

85. Harriman, L.G., III; Judge, J. Dehumidification equipment advances. ASHRAE J. 2002, 44, 22-29.

86. McGahey, K. New commercial applications for desiccant-based cooling. ASHRAE J. 1998, 40, 41-45.

87. Yu, N.; Wang, R.; Lu, Z.; Wang, L. Development and characterization of silica gel-LiCl composite sorbents for thermal energy storage. Chem. Eng. Sci. 2014, 111, 73-84. [CrossRef]

88. Simonova, I.A.; Freni, A.; Restuccia, G.; Aristov, Y.I. Water sorption on composite "silica modified by calcium nitrate". Microporous Mesoporous Mater. 2009, 122, 223-228. [CrossRef]

89. Cortés, F.B.; Chejne, F.; Carrasco-Marín, F.; Perez-Cadenas, A.F.; Moreno-Castilla, C. Water sorption on silica- and zeolitesupported hygroscopic salts for cooling system applications. Energy Convers. Manag. 2012, 53, 219-223. [CrossRef]

90. Chen, H.-J.; Cui, Q.; Tang, Y.; Chen, X.-J.; Yao, H.-Q. Attapulgite based LiCl composite adsorbents for cooling and air conditioning applications. Appl. Therm. Eng. 2008, 28, 2187-2193. [CrossRef]

91. Tso, C.Y.; Chao, C.Y. Activated carbon, silica-gel and calcium chloride composite adsorbents for energy efficient solar adsorption cooling and dehumidification systems. Int. J. Refrig. 2012, 35, 1626-1638. [CrossRef]

92. Seo, Y.-K.; Yoon, J.W.; Lee, J.S.; Hwang, Y.K.; Jun, C.-H.; Chang, J.-S.; Wuttke, S.; Bazin, P.; Vimont, A.; Daturi, M.; et al. EnergyEfficient Dehumidification over Hierachically Porous Metal-Organic Frameworks as Advanced Water Adsorbents. Adv. Mater. 2012, 24, 806-810. [CrossRef]

93. Akiyama, G.; Matsuda, R.; Sato, H.; Hori, A.; Takata, M.; Kitagawa, S. Effect of functional groups in MIL-101 on water sorption behavior. Microporous Mesoporous Mater. 2012, 157, 89-93. [CrossRef] 
94. Henninger, S.K.; Jeremias, F.; Kummer, H.; Janiak, C. MOFs for use in adsorption heat pump processes. Eur. J. Inorg. Chem. 2012, 2012, 2625-2634. [CrossRef]

95. Thorpe, G. The modelling and potential applications of a simple solar regenerated grain cooling device. Postharvest Biol. Technol. 1998, 13, 151-168. [CrossRef] 